\title{
Het ligt in de verwachting dat problemen toenemen
}

\author{
In de Veenkoloniën komt meer dan de helft van de mensen die het wettelijke schuldsaneringstraject \\ volgen uit een gezin dat inkomen uit werk of een onderneming ontvangt. Gezien de huidige \\ economische crisis is het dus alle hens aan dek om ook voor deze groep een toename in \\ schuldproblemen te voorkomen.
}

DOOR Erik Merx, Arjen Edzes en Sanne Visser

$\mathrm{P}$ roblematische schulden komen in de Veenkoloniën relatief het meest voor bij economisch kwetsbare groepen zoals eenoudergezinnen, gezinnen met lage inkomens en gezinnen die een bijstandsuitkering ontvangen.

Armoede- en schuldvraagstukken zijn in het licht van de huidige COVID-19 pandemie een belangrijk onderwerp. Economisch kwetsbare groepen hebben door het verliezen van inkomsten als gevolg van COVID-19 een verhoogde kans op het maken van schulden. Vanaf begin 2021 treedt er een wetswijziging in werking waardoor gemeenten mensen met betalingsachterstanden en schulden eerder schuldhulpverlening kunnen aanbieden. Het uitwisselen van informatie over betalingsachterstanden met woningcorporaties, energie- en drinkwaterbedrijven en zorgverzekeraars wordt dan mogelijk gemaakt. Gemeenten doen er echter goed aan om zich ook te richten op de groepen die problemen ondervinden met het betalen van hun basisbehoeften voordat er een betalingsachterstand is ontstaan. Mensen die moeite hebben met het betalen van onmisbare zaken zoals voedsel, kleding, persoonlijke verzorging of wonen, lopen eerder tegen schuldproblemen op een later moment aan (Nibud, 2020). In de Veenkoloniën (zie figuur 2) hebben we een eerste verkenning uitgevoerd. In dit gebied in OostGroningen en Zuidoost-Drenthe komt relatief veel (generatie)armoede voor (Edzes \& Strijker, 2017). De groep mensen onder de armoedegrens in de Veenkoloniën is divers. Naast de groep met een uitkering heeft circa een kwart van de armen een inkomen uit loondienst of als zzp'er (Edzes et al. 2019). Arme ouders hebben in het gebied vijf keer vaker arme kinderen dan niet arme ouders, wat duidt op generatiearmoede (CMO STAMM \& RuG, 2019). In tegenstelling tot de grote steden komt armoede in dit gebied vooral onder de groep autochtone inwoners voor. De belangrijkste oorzaak daarvan is dat er weinig (niet-)westerse minderheden in de Veenkoloniën wonen. De hardnekkige armoede in het gebied was in 2017 de aanleiding een breed offensief te starten om generatiearmoede beter te doorgronden en bestrijden. Verenigd in de Alliantie van Kracht hebben organisaties als de Tinten welzijnsorganisatie, GGD en ggz, woningbouwcorporaties en zorginstellingen samen met de lokale en regionale overheden de handen ineengeslagen. Parallel aan dit initiatief is de Rijksuniversiteit Groningen gestart met een onderzoek naar intergenerationele armoede, gefinancierd door de provincies Groningen en Drenthe. In de verkenning naar schuldenproblematiek zijn eerst de relaties tussen persoonlijke en huishoudkenmerken en schulden onderzocht. Daarna hebben we gekeken naar generatiearmoede (intergenerationele overdracht) en de invloed van de buurt waar iemand woont (buurteffecten).

\section{Schuldhulpverlening}

We hebben gekeken naar de mensen die in het kader van de Wet schuldsanering voor natuurlijke personen (Wsnp) een schuldsaneringstraject doorlopen. De Wsnp is opgezet als een laatste redmiddel voor mensen die in een levenslange problematische schuldensituatie dreigen te raken. Zoals figuur 1 laat zien, dienen mensen met schulden eerst een verzoek te doen tot schuldhulpverlening bij een particuliere schuldhulpverlener of bij de gemeente waarin zij wonen. Gemeenten hebben sinds 2012 de wettelijke taak om deze schuldhulpverlening aan te bieden. Wanneer het niet lukt om tot een

\section{Klaarblijkelijk trekken sommige buurten meer}




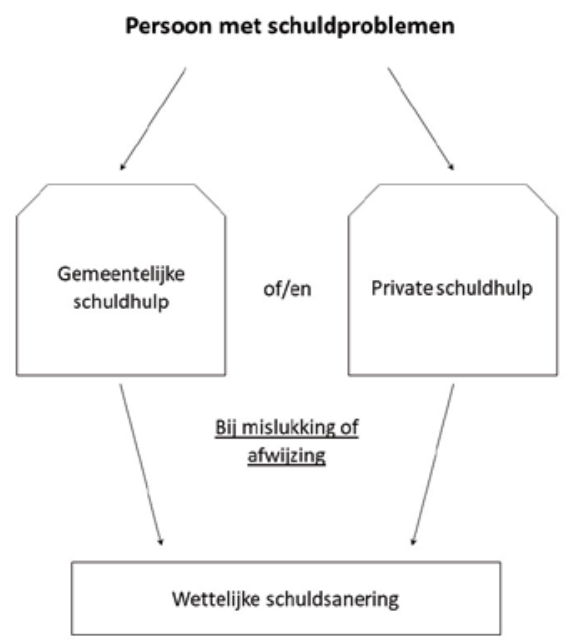

Figuur 1: De mogelijkheden tot schuldhulpverlening in Nederland.

vrijwillige regeling te komen dan kan een beroep worden gedaan op de Wsnp. Door deze wet kan een rechter schuldeisers verplichten om mee te werken aan een schuldsaneringstraject dat drie tot vijf jaar duurt. Wanneer mensen zijn toegelaten tot de Wet schuldsanering voor natuurlijke personen spreken we in dit onderzoek van een problematische schuld.

Niet alle aanvragen tot de Wet schuldsanering worden door een rechter gehonoreerd. Zo werd in de periode 2016-2017 circa 40 procent van het totale aantal aanvragen afgewezen (Raad voor Rechtsbijstand, 2018). Rechters wijzen een verzoek bijna altijd af wanneer een schuldenaar veroordeeld is geweest voor een misdrijf of fraudezaak. Verder dienen de schulden te goeder trouw te zijn ontstaan en moet de rechter verwachten dat de schuldenaar zijn financiële verplichtingen zal nakomen. Eenmaal in het wettelijke schuldsaneringstraject dienen schuldenaren zoveel mogelijk inkomsten te verwerven om zo bij te dragen aan het afbetalen van de schuld. Tijdens het saneringstraject zijn zij niet bevoegd zelf financiële beslissingen te nemen, de rechter wijst hun een 'weinig maar toereikend budget' toe. In de praktijk is dit net voldoende om de meest noodzakelijke boodschappen te doen. Een cadeautje voor onder de kerstboom kopen is voor de meeste mensen die van dit budget leven niet haalbaar.

\section{Ruimtelijke spreiding}

In de Veenkoloniën wordt relatief veel gebruik gemaakt van de Wsnp. Zo volgden 1 op de 139 volwassen inwoners $(0,72 \%)$ van de Veenkoloniën in 2017 dit wettelijke schuldsaneringstraject. Dat is ruim tweemaal zo veel als in heel Nederland. Figuur 2 laat zien dat er tussen de onderzochte gemeenten behoorlijke verschillen zijn in het relatieve aantal problematische schulden. Dit kunnen we verklaren door verschillen in de bevolkingssamenstelling tussen deze gemeenten. Zo zijn sommige dorpen in de Drentse gemeenten door hun ligging op zandgronden erg in trek als woonplaats onder kapitaalkrachtige tweeverdieners en senioren (Movisie, 2012). Hierdoor wonen er relatief meer kapitaalkrachtige mensen in deze gemeenten, wat we terugzien in de relatief lagere percentages problematische schulden.

\section{Inkomen}

De oorzaken van schulden kunnen net zoals bij armoede verklaard worden vanuit drie invalshoeken. Zo kunnen problematische schulden worden toegeschreven aan (1) gedrag, (2) beleid en (3) de structurele context (Brady,
2019). Onder structurele context verstaan we hier de fysieke en sociale kenmerken van de buurt en daar hebben wij in dit onderzoek vooral naar gekeken. Hierin is een onderscheid gemaakt tussen persoonlijke en huishoudkenmerken, intergenerationele relaties en de kenmerken van de buurt waar iemand woont.

Problematische schulden komen in de Veenkoloniën met name voor onder huishoudens met een laag inkomen. Zo hebben mensen uit de groep van de 20 procent armste huishoudens 25 keer vaker een problematische schuld dan mensen uit de groep van de 20 procent rijkste huishoudens. Huishoudens met lage inkomens hebben een (te) kleine buffer om onverwachte kosten en rekeningen op te vangen. Vooral onverwachte rekeningen, verhogingen door te laat betaalde facturen en problemen rond te veel ontvangen toeslagen leiden tot schuldproblemen (WRR, 2016).

In figuur 3 hebben wij de inkomensgegevens verder uitgesplitst naar de belangrijkste inkomstenbron van het

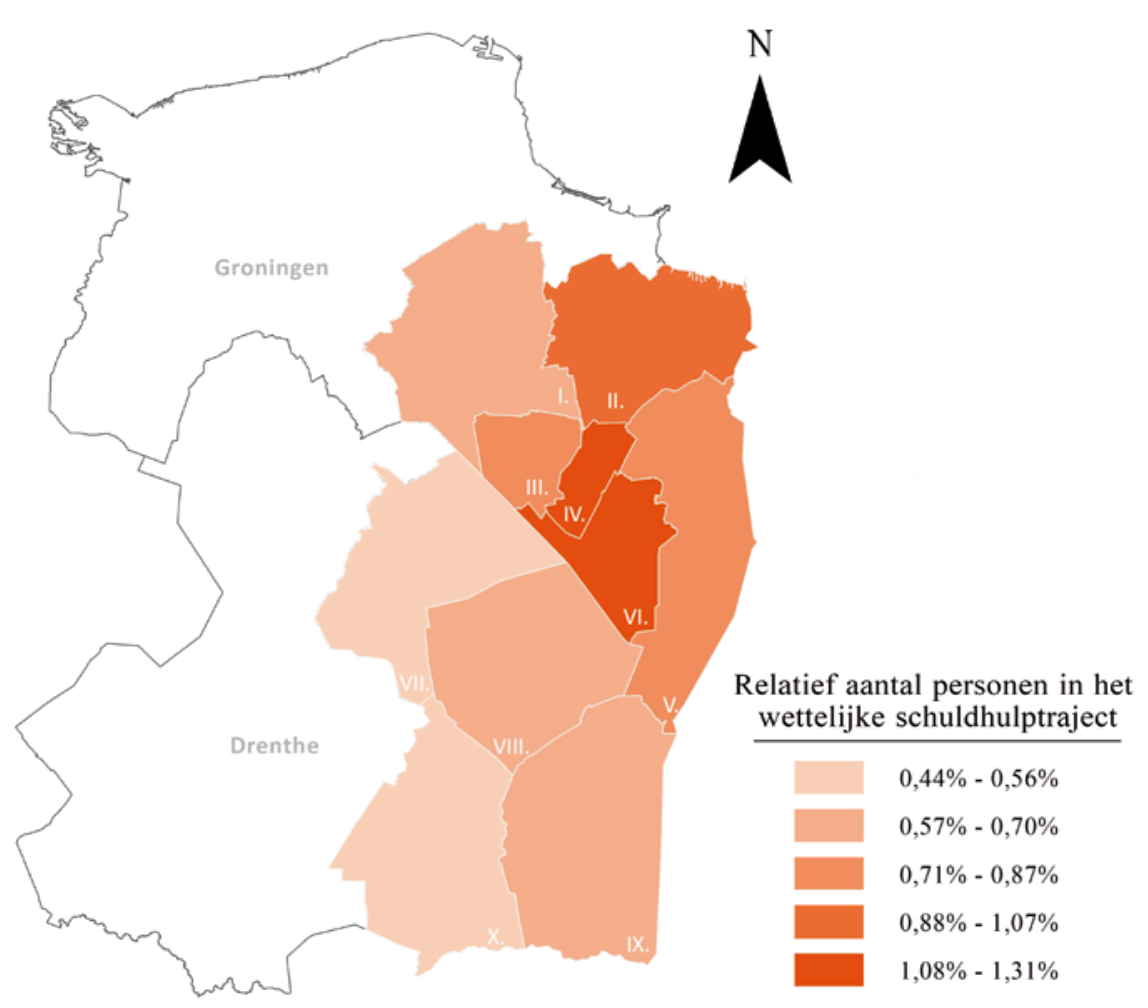

I. MIDDEN-GRONINGEN II. OLDAMBT III. VEENDAM IV. PEKELA V. WESTERWOLDE VI. STADSKANAAL VII AA EN HUNZE VIII. BORGER-ODOORN IX. EMMEN X. COEVORDEN

Figuur 2: Relatief gezien kwamen problematische schulden in het jaar 2017 het meest voor in de Groningse gemeenten Pekela (1,31\%), Stadskanaal $(1,20 \%)$ en Oldambt $(0,97 \%)$. Het landelijke gemiddelde was dat jaar 0,32 procent. Bron: CBS Microdata, eigen bewerkingen. 


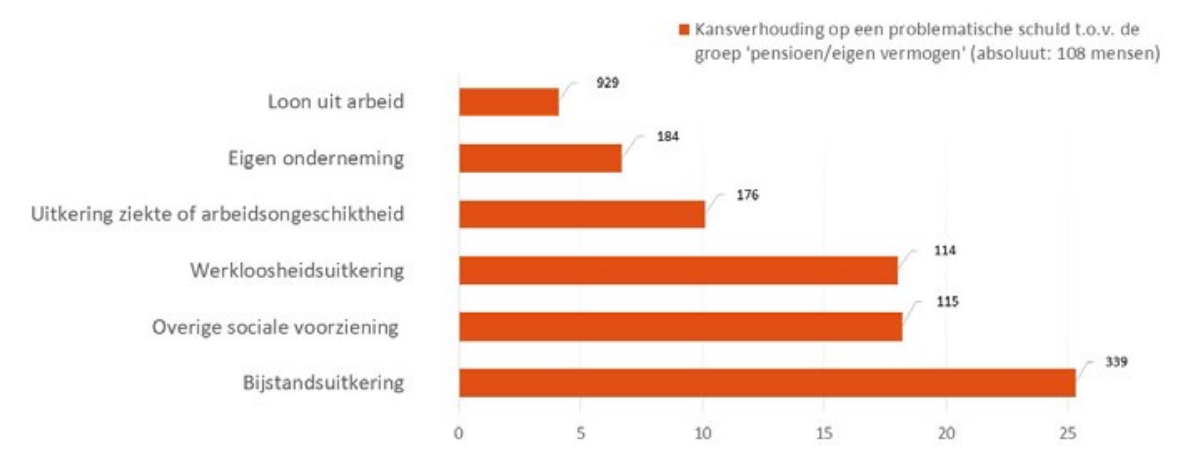

Figuur 3: Kansverhouding op een problematische schuld t.o.v. de groep 'pensioen/eigen vermogen' en de voornaamste inkomstenbron drie jaar voor start schuldsaneringstraject, jaar 2017. Bron: CBS Microdata, eigen bewerkingen.

huishouden drie jaar voorafgaand aan de schuldsanering. We weten immers dat het vanaf de eerste betalingsachterstanden gemiddeld vijf jaar duurt voordat mensen met schuldproblemen om hulp vragen (Jungmann \& Anderson, 2011). We hebben allereerst naar de kansverhoudingen tussen de onderscheiden groepen gekeken. Met de kansverhoudingen worden de verhoudingen ten opzichte van een vergelijkingsgroep weergegeven. Als referentie hebben wij de groep met relatief het laagste aantal problematische schulden gekozen, namelijk de groep met pensioen of eigen vermogen als voornaamste inkomstenbron van het huishouden. Zo heeft iemand met inkomsten uit een eigen onderneming circa 7 keer vaker een problematische schuld dan iemand uit de groep pensioen of eigen vermogen, en bijstandsgerechtigden ruim 25 keer vaker.

De getallen achter de staafjes geven de groepsgrootte aan. Van de 1.965 mensen die in 2017 deelnamen aan het wettelijke schuldsaneringstraject hebben we inkomensgegevens beschikbaar. Ongeveer de helft van hen had drie jaar voorafgaand daaraan inkomen uit arbeid. Ondernemers werden (tot aan de COVID-19 uitbraak) weinig geassocieerd met problematische schulden. Toch komt ongeveer 10 procent van de deelname aan de wettelijke schuldsanering voor rekening van (voormalig) ondernemers.

Economisch kwetsbare groepen hebben de grootste kans op een problematische schuld, maar de relatie met generatiearmoede is zwak. Eenoudergezinnen met minderjarige kinderen, praktisch opgeleiden en huishoudens die van een (bijstands)uitkering afhankelijk zijn, hebben relatief gezien het vaakst een problematische schuld in de Veenkolonien. Ons beeld wordt bevestigd door recent onderzoek van het Nibud (2020) waaruit blijkt dat de huidige inkomensondersteuningsmaatregelen zoals de bijstandsuitkering niet toereikend zijn. Verder zien we dat mensen met een arme moeder iets meer dan twee vaker een problematische schuld hebben. Voor mensen met een arme vader was dit circa anderhalf keer zo vaak. De verschillen zijn echter zo klein dat ze ook op toeval kunnen berusten.

\section{Buurteffecten}

In sommige buurten in de Veenkoloniën wonen opvallend meer mensen met problematische schulden. Dit kan deels verklaard worden door verschillen in de bevolkingssamenstelling tussen buurten. Hierdoor wonen in sommige buurten bijvoorbeeld meer inwoners met een laag inkomen, waardoor er in die buurten relatief meer problematische schulden voorkomen. Ook als we hier rekening mee houden, blijft er een verschil op buurtniveau over dat we niet aan toeval kunnen toeschrijven. Klaarblijkelijk trekken sommige buurten meer mensen met potentiële schuldproblemen aan en houden ze die mensen ook vast. Hierdoor kan in deze buurten een normalisatie van schulden ontstaan, wat weer een versterkend effect heeft op de problematiek (Sharkey, 2013). Gezien de huidige COVID-19 pandemie kunnen we een toename in het aantal schuldproblemen verwachten. Voor de uitbraak volgden al relatief veel mensen in de Veenkoloniën het wettelijke schuldsaneringstraject. Deze schulden kennen niet zozeer een intergenerationele oorzaak, maar kunnen gedeeltelijk verklaard worden aan de hand van persoonlijke en huishoudkenmerken. Hoewel wij het vroeger ingrijpen bij betalingsachterstanden van harte toejuichen, worden hiermee de structurele oorzaken van de betalingsachterstanden niet aangepakt. De focus moet blijven op het voorkomen van deze achterstanden. Daarbij ligt de bal deels bij het Rijk en deels bij de gemeenten. Het Rijk kan helpen door landelijke uitkeringen zoals de bijstandsnorm te verhogen, de beschikbaarheid van consumentenkredieten aan banden te leggen en hervormingen door te voeren in de momenteel complexe toeslagensystematiek. Gemeenten kunnen hun inwoners helpen door aanvraagprocedures te vereenvoudigen en grondiger te communiceren, om zo de doelgroep beter te bereiken en van dienst te zijn. Daarnaast doen zij er goed aan ruimhartiger te zijn in het openstellen van regelingen zoals de collectieve zorgverzekeringen en minimaregelingen voor flexwerkers en zzp'ers. Het spreekt voor zich dat het Rijk gemeenten hiervoor financieel tegemoet moet komen, omdat gemeenten nu al (ernstige) problemen hebben met het rondkrijgen van hun begroting in het sociaal domein.

We hebben laten zien dat het van belang is dat gemeenten hun economisch kwetsbare groepen - de mensen die hun basisbehoeften nauwelijks kunnen betalen - scherp in beeld hebben, overeenkomstig het Nibud-advies (2020). Het wringt financieel bij de hiervoor genoemde kwetsbare groepen en het is terecht dat mensen zich zorgen maken. De groep werkenden en ondernemers heeft echter vaker problematische schulden dan werd verwacht. Voor een deel van deze groep was het dus al vijf voor twaalf voordat de COVID-19 pandemie uitbrak.

De auteurs zijn allen werkzaam bij de faculteit Ruimtelijke Wetenschappen van de Rijksuniversiteit Groningen.

\section{Noten}

1. Wij hebben de voornaamste inkomstenbron van het huishouden waarvan iemand deel uitmaakt gemeten. Hierbij gaan wij ervan uit dat de overige leden van een huishouden financieel hulp bieden wanneer een lid van het huishouden een betalingsachterstand oploopt.

2. In tegenstelling tot alleen kansen die slechts de individuele waarschijnlijkheid waarmee iets gebeurt laten zien. 